\title{
Pemberian Berbagai Dosis Bokashi Jerami Padi yang Difermentasikan dengan PGPR Akar Bambu pada Tanaman Kedelai
}

\section{(Giving Various Dosages of Bokashi Rice Straw Which are Fermented with Bamboo Root PGPR on Soybean Plants)}

\author{
Sariyu Erwan'), Nurul Istiqomah ${ }^{2)}$ \& Mahdiannoor $^{3)}$ \\ Program Studi Agroteknologi Sekolah Tinggi Ilmu Pertanian Amuntai \\ ${ }^{1)}$ sariyuirwana@gmail.com \\ ${ }^{2)}$ qoqom_81@yahoo.co.id \\ ${ }^{3)}$ mahdi_186@yahoo.com
}

\begin{abstract}
ABSTRAK
Kedelai biasanya akan tumbuh baik pada ketinggian tidak lebih dari 500 hingga $600 \mathrm{~m}$ dpl. Iklim kering lebih disukai tanaman kedelai dibandingkan iklim lembab. Jerami adalah bagian vegetatif tanaman padi (batang, daun, tangkai malai) yang tidak dipungut saat tanaman padi dipanen. Salah satu pupuk organik jerami padi yaitu bokashi. Bokashi jerami padi mengandung beberapa unsur organik esensial yang dibutuhkan oleh tanaman. Plant Growth Promoting Rhizobacteria $(P G P R)$, merupakan salah satu agens hayati yang telah banyak digunakan dan teruji untuk mengendalikan berbagai patogen tanaman, memanfaatkan akar bambu sebagai dekomposer karena pada akar bambu terdapat bakteri Pseudomonas flourenscens dan bakteri Bacillus polymixa yang dapat membantu proses fermentasi. Tujuan penelitian (i) mengetahui pengaruh pemberian dan (ii) mendapatkan dosis bokashi jerami padi terbaik terhadap pertumbuhan dan hasil tanaman kedelai. Penelitian dilaksanakan di Desa Pembakulan Kecamatan Batang Alai Timur Kabupaten Hulu Sungai Tengah dari bulan April - Agustus 2018Penelitian ini menggunakan Rancangan Acak Kelompok (RAK) faktor tunggal, Pengelompokkan berdasarkan distribusi cahaya matahari. Faktor yang di teliti adalah dosis bokashi jerami padi $(j)$ sebanyak 4 perlakuan terdiri dari $j_{1}=1,3 \mathrm{~kg}$ per petak, $j_{2}=2,6 \mathrm{~kg}$ petak, $j_{3}=3,9 \mathrm{~kg}$ per petak dan $j_{4}=5,2 \mathrm{~kg}$ per petak. Faktor yang diamati tinggi tanaman, jumlah daun, umur berbunga, jumlah polong, jumlah biji, dan berat kering 100 kedelai. Hasil penelitian tidak menunjukan adanya pengaruh pemberian bokashi jerami padi terhadap tanaman kedelai.
\end{abstract}

Kata Kunci: Kedelai, jerami padi, bokashi, PGPR, akar bambu.

\section{ABSTRACT}

Soybeans will usually grow well at an altitude of no more than 500 to $600 \mathrm{~m}$ above sea level. The dry climate is preferred by soybean plants compared to the humid climate. Straw is a vegetative part of rice plants (stems, leaves, pan stalks) that are not collected when the rice plants are harvested. -One of the bokashi rice straw organic fertilizers. Bokashi rice straw contains some essential organic elements needed by plants. Plant Growth Promoting Rhizobacteria (PGPR), is one of the biological agents that has been widely used and tested to control various plant pathogens, utilizing bamboo roots as decomposers because in the bamboo roots there are bacteria Pseudomonas flourescent and Bacillus polymixa which can help the fermentation process. The aim of the study (i) was to find out the effect of giving and (ii) to get the best bokashi rice straw dose on the growth and yield of soybean plants. The study was carried out in Pembakulan Village Batang Alai Timur District, Hulu Sungai Tengah Regency from April to August 2018. This study used a single factor randomized design (RBD), grouping based on sunlight distribution. The factors examined were 4 bokashi rice straw doses (j) consisting of $j_{1}=1.3 \mathrm{~kg}$ per plot, $j_{2}=2.6 \mathrm{~kg}$ plot, $j_{3}=3.9 \mathrm{~kg}$ per plot and $j_{4}=5.2 \mathrm{~kg}$ per plot plot . Factors observed were plant height, leaf number, flowering age, number of pods, number of seeds, and dry weight of 100 soybeans. The results of the study did not indicate the effect of bokashi rice straw on soybean plants.

Keywords: Soybean, rice straw, bokashi, PGPR, bamboo root. 


\section{PENDAHULUAN}

Kedelai (Glycine max (L.) Merill) merupakan salah satu komoditas pertanian yang banyak dikonsumsi oleh aneka industri pangan dan rumah tangga di Indonesia. Berkembangnya aneka industri berbahan baku kedelai di Indonesia, telah mendorong meningkatkan permintaan komoditas kedelai dari tahun ke tahun. Sedangkan, pasokan komoditas kedelai lokal masih belum memenuhi tingginya permintaan. Kebutuhan kedelai dalam negeri sebagian besar masih dipasok oleh produk impor. Berdasarkan data Litbang Deptan Tahun 2010, kebutuhan kedelai Indonesia kurang lebih 2,4 juta t.tahun ${ }^{-1}$, dan konsumsi terbesar komoditas kedelai adalah industri tahu dan tempe berkisar 70$80 \%$, kemudian disusul industri kecap. Volume impor kedelai selama tahun 20022007 rata-rata mencapai $63,94 \%$ dari total kebutuhan dalam negeri (Salim, 2012).

Saat ini produktivitas nasional kedelai baru mencapai 1,56 t.ha ${ }^{-1}$ dengan kisaran 0,8-2,4 t.ha ${ }^{-1}$ di tingkat petani, sedangkan di tingkat penelitian sudah mencapai 1,7-3,2 t.ha ${ }^{-1}$, bergantung pada kondisi lahan dan teknologi yang diterapkan (Badan Litbang Pertanian, 2016). Produktivitas kedelai di Kabupaten Hulu Sungai Tengah berdasarkan data BPS Hulu Sungai Tengah (2014, 2015, 2016, 2017) disebutkan bahwa pada tahun 2013 sebesar 1,240 t.ha-1, tahun 2014 sebesar 1,275 t.ha-1, tahun 2015 sebesar 1,276 t.ha 1 dan tidak terjadi peningkatan produktivitas pada tahun 2016. Hal ini menunjukkan bahwa produktivitas kedelai di Kabupaten Hulu Sungai Tengah masih rendah dibawah produktivitas nasional.

Menurut Pambudi (2013), untuk dapat berproduksi optimal, tanaman kedelai memerlukan tanah dengan tekstur berlempung atau berliat, solum sedangdalam, drainase sedang-baik, hara NPK dan unsur hara mikro sedang-tinggi, $\mathrm{pH}$ tanah 5,8 - 7,0. Sedangkan pada tanah yang akan menjadi tempat penelitian mempunyai $\mathrm{pH} \mathrm{H}_{2} \mathrm{O} 5,15$ (masam), N-total 0,108 (sedang), $\mathrm{P} 3,748$ (tinggi), dan $\mathrm{K}$ 17,211 (tinggi).
Peningkatan produktivitas dan kualitas kedelai harus diupayakan dengan cara-cara yang lebih baik, seperti menggunakan pupuk organik. Selanjutnya Abdurahman (2005), dalam Efendi (2010) mengatakan sumber pupuk organik dapat berasal dari berbagai biomas atau bahan organik, seperti sisa tanaman atau hewan. Setiap bahan organik memiliki kandungan atau komposisi unsur hara yang berbedabeda. Jenis apa dan dosis berapa yang tepat untuk meningkatkan pertumbuhan dan produksi kedelai belumlah diketahui dengan pasti. Dosis pupuk organik direkomendasikan untuk kedelai adalah 20-30 t.ha- ${ }^{-1}$.

Salah satu pupuk organik yaitu bokashi jerami padi. Bokashi jerami padi mengandung beberapa unsur organik esensial yang dibutuhkan oleh tanaman (Susmiati, 2013). Pada penelitian Sakhidin dan Iqbal (2008) dalam Mulyana et. al., (2011), bahwa peningkatan pemberian dosis bokashi dari 0 sampai dengan 15 t.ha ${ }^{1}$ meningkatkan tinggi tanaman dan jumlah anakan produktif secara linear. Pemberian bokashi lebih dari 15 t.ha $^{-1}$ masih dapat meningkatkan pertumbuhan tanaman padi.

Jerami padi terdiri atas daun, pelepah dan ruas atau buku. Ketiga unsur ini relatif kuat karena mengandung silika, dan selulosa yang tinggi dan pelapukannya memerlukan waktu yang lama. Namun, apabila jerami padi diberi perlakuan tertentu akan mempercepat terjadinya perubahan strukturnya (Kusumawardhani, 2015). Salah satu perlakuan tersebut adalah penambahan PGPR. Susetyo (2013) memanfaatkan akar bambu sebagai dekomposer karena pada akar bambu terdapat bakteri Pseudomonas flourenscens dan bakteri Bacillus polymixa yang dapat membantu proses fermentasi. Tujuan penelitian (i) mengetahui pengaruh pemberian dan (ii) mendapatkan dosis bokashi jerami padi terbaik terhadap pertumbuhan dan hasil tanaman kedelai.

\section{METODE PENELITIAN}

Penelitian ini dilaksanakan di Desa Pembakulan Kecamatan Batang Alai 
Sariyu Erwan, Nurul Istiqomah \& Mahdiannoor, Pemberian berbagai dosis bokashi...

Timur Kabupaten Hulu Sungai Tengah. Penelitian dari bulan April - Agustus 2018. Bahan yang digunakan adalah benih kedelai Varietas Anjasmoro, lahan dengan jenis tanah podsolik, bokashi jerami padi, PGPR akar bambu, pupuk kandang kotoran sapi, air, dan pestisida. Alat yang dipakai antara lain cangkul, sekop, parang, tugal, alat tulis, gembor, ember, hand sprayer, meteran, kamera, gunting, dan timbangan. Penelitian ini merupakan percobaan yang dilakukan dilapangan dengan menggunakan Rancangan Acak Kelompok (RAK) dengan faktor tunggal pengelompokkan berdasarkan distribusi cahaya matahari dilapangan percobaan, faktor yang di teliti adalah dosis bokashi jerami padi (J) sebanyak 4 perlakuan, terdiri dari : $\left(\mathrm{j}_{1}=10 \mathrm{t}^{-h^{-1}}\right.$ setara $1,3 \mathrm{~kg}$. petak $\left.^{-1}\right), \quad\left(j_{2}=20\right.$ t.ha ${ }^{-1}$ setara 2,6 kg. petak $\left.{ }^{1}\right),\left(j_{3}=30\right.$ t.ha $^{-1}$ setara $3,9 \mathrm{~kg}$. petak $\left.{ }^{-1}\right)$, dan $\left(j_{4}=40\right.$ t.ha $^{-1}$ setara 5,2 kg. petak $\left.{ }^{-1}\right)$. Setiap perlakuan diulang sebanyak 6 kali, sehingga terdapat 24 satuan percobaan. Setiap percobaan ada 4 tanaman sampel, sehingga semuanya ada 96 tanaman sampel yang diamati. Pengamatan yang dilakukan adalah tinggi tanaman, jumlah daun, umur berbunga, jumlah cabang produktif, jumlah polong, jumlah biji per tanaman dan berat 100 biji. Untuk mengetahui pengaruh perlakuan terhadap peubah yang diamati di lakukan uji homogenan ragam bartlet terlebih dahulu, apabila homogen kemudian di lanjutkan analisis ragam menggunakan uji $\mathrm{F}$ pada taraf nyata atau sangat nyata $5 \%$ dan $1 \%$. Jika $\mathrm{F}$ hitung $>\mathrm{F}$ tabel $5 \%$ dan $1 \%$ berarti perlakuan berpengaruh nyata atau sangat nyata, kemudian dilanjutkan dengan uji DMRT pada taraf uji 5\% untuk mengetahui nilai tengah rata-rata terbaik (Langai, 2003).

\section{HASIL DAN PEMBAHASAN}

\section{Hasil}

\section{Tinggi Tanaman}

Berdasarkan hasil analisis ragam menunjukan bahwa pemberian dosis bokashi jerami padi tidak berpengaruh pada umur 14, 21dan 28 HST terhadap tinggi tanaman kedelai. Hubungan pemberian dosis bokashi jerami padi terhadap tinggi tanaman kedelai dapat dilihat pada Gambar 1.

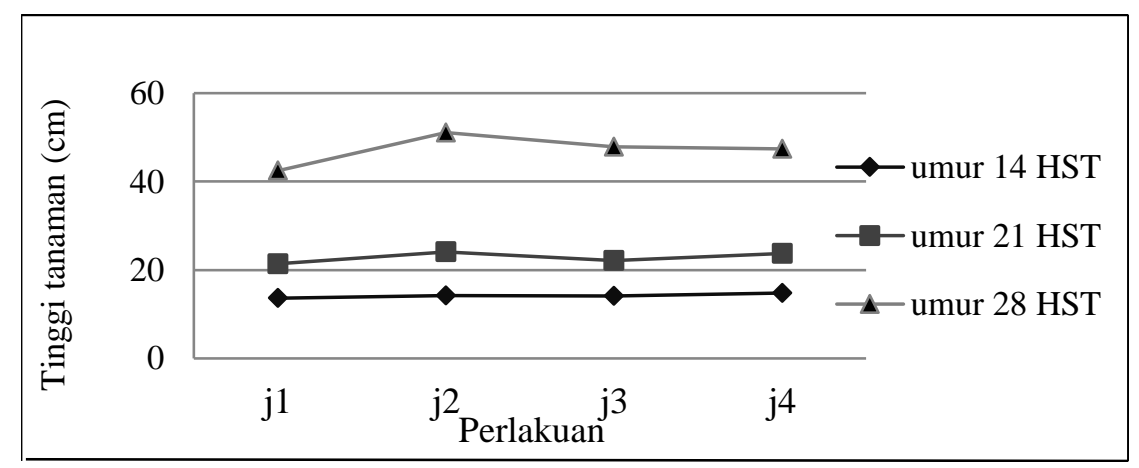

Gambar 1. Grafik pemberian dosis bokashi jerami padi terhadap tinggi tanaman kedelai umur 14, 21, dan 28 HST.

Dari gambar terlihat bahwa pemberian bokashi jerami padi terhadap tanaman kedelai pada umur 14 HST menghasilkan nilai rata-rata tertinggi yaitu perlakuan $\mathrm{j}_{4}(14,79 \mathrm{~cm})$, dan yang terendah pada perlakuan $\mathrm{j}_{1}$ dengan nilai rata-rata $13,62 \mathrm{~cm}$. Umur $21 \mathrm{HST}$ nilai rata-rata tertinggi dihasilkan pada perlakuan $\mathrm{j}_{2}$ $(24,08 \mathrm{~cm})$ dan yang terendah pada perlakuan $\mathrm{j}_{1}$ dengan nilai rata-rata 21,41 cm. Dan umur 28 HST nilai rata-rata tertinggi dihasilkan pada perlakuan $\mathrm{j}_{2}$ $(51,08 \mathrm{~cm})$ dan yang terendah pada perlakuan $\mathrm{j}_{1}$ dengan nilai rata-rata 42,45 $\mathrm{cm}$.

\section{Jumlah Daun}

Berdasarkan hasil analisis ragam menunjukan bahwa pemberian dosis 
bokashi jerami padi tidak berpengaruh pada umur 14, 21 dan 28 HST terhadap jumlah daun. Hubungan pemberian dosis bokashi jerami padi terhadap jumlah daun tanaman kedelai dapat dilihat pada Gambar 2.

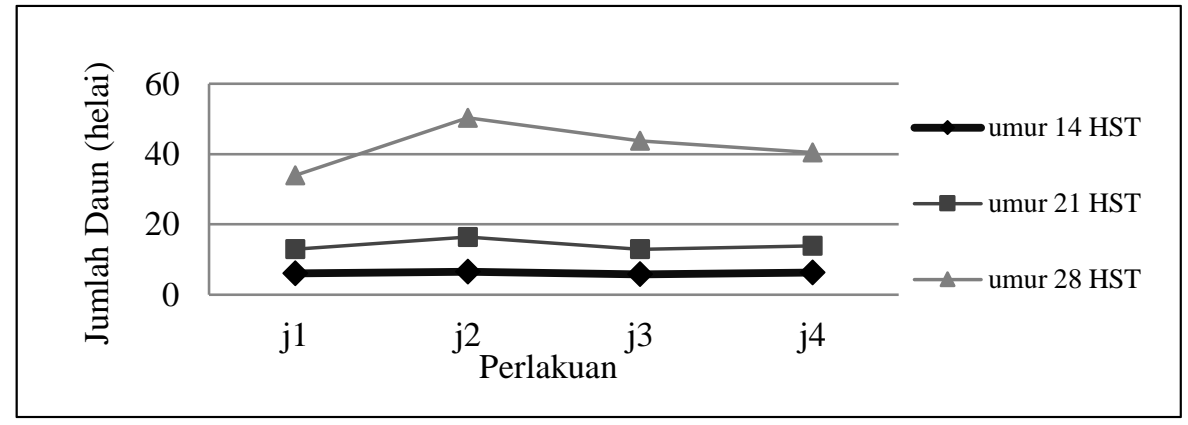

Gambar 2. Grafik pemberian dosis bokashi jerami padi terhadap jumlah daun tanaman kedelai umur 14, 21, dan 28 HST.

Dari gambar terlihat bahwa pemberian bokashi jerami padi terhadap tanaman kedelai pada umur 14 HST menghasilkan nilai rata-rata terbanyak yaitu perlakuan $\mathrm{j}_{2}$ (6,54 helai), dan paling sedikit pada perlakuan $\mathrm{j}_{3}$ dengan nilai rata-rata 5,79 helai. Umur 21 HST nilai rata-rata terbanyak dihasilkan pada perlakuan $\mathrm{j}_{2}$ (16,41 helai) dan yang sedikit pada perlakuan $\mathrm{j}_{3}$ dengan nilai rata-rata 12,91 helai. Umur 28 HST nilai rata-rata terbanyak dihasilkan pada perlakuan $\mathrm{j}_{2}$ 50,33 helai dan yang paling sedikit dihasilkan pada perlakuan $\mathrm{j}_{1}$ dengan nilai rata-rata 33,95 helai.

\section{Umur Berbunga Tanaman}

Berdasarkan hasil analisis ragam menunjukan bahwa pemberian dosis bokashi jerami padi tidak berpengaruh terhadap umur berbunga kedelai. Hubungan pemberian dosis bokashi jerami padi terhadap umur berbunga tanaman kedelai dapat dilihat pada Gambar 3.

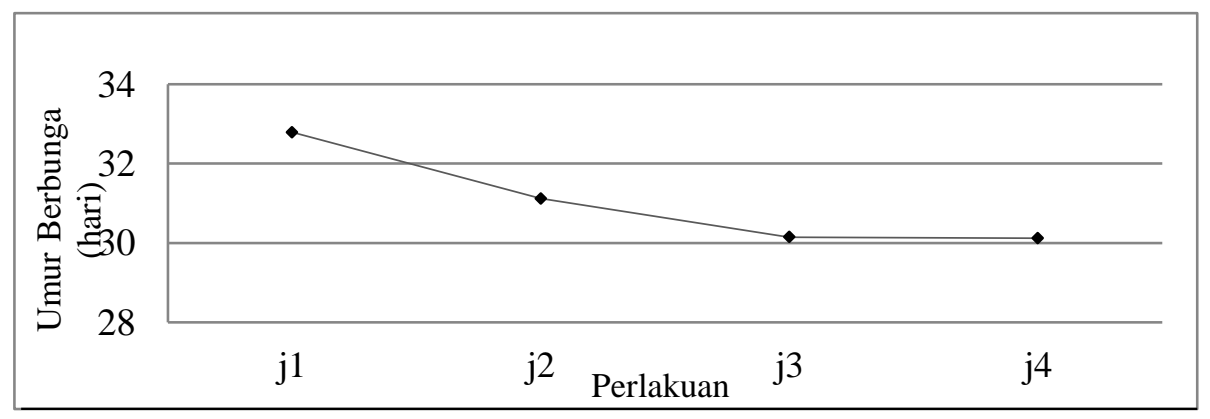

Gambar 3. Grafik pemberian dosis bokashi jerami padi terhadap umur berbunga pada tanaman kedelai.

Dari gambar terlihat bahwa pemberian dosis bokashi jerami padi menghasilkan umur berbunga tercepat pada perlakuan $\mathrm{j}_{4}$ dengan nilai rata-rata 30,12 hari dan umur berbunga agak terlambat dihasilkan pada perlakuan $\mathrm{j}_{1}$ dengan nilai rata-rata 32,79 hari.

\section{Jumlah Cabang}

Berdasarkan hasil dari analisis ragam menunjukan bahwa pemberian dosis bokashi jerami padi tidak berpengaruh terhadap jumlah cabang tanaman kedelai. Hubungan pemberian dosis bokashi jerami padi terhadap jumlah cabang tanaman kedelai dapat dilihat pada Gambar 4. 
Sariyu Erwan, Nurul Istiqomah \& Mahdiannoor, Pemberian berbagai dosis bokashi...

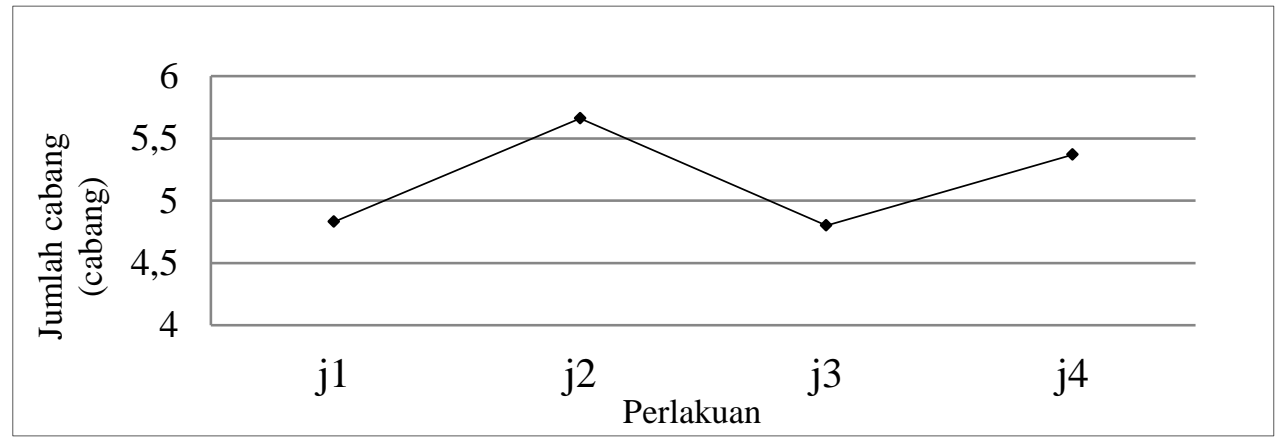

Gambar 4. Grafik pemberian dosis bokashi jerami padi terhadap jumlah cabang pada tanaman kacang kedelai.

Dari gambar terlihat bahwa pemberian dosis bokashi jerami padi menghasilkan jumlah cabang tanaman kedelai yang terbanyak pada perlakuan $\mathrm{j}_{2}$ dengan nilai rata-rata 5,66 cabang dan jumlah cabang yang sedikit pada perlakuan $\mathrm{j}_{3}$ dengan nilai rata-rata 4,8 cabang.
Berdasarkan hasil dari analisis ragam menunjukan bahwa pemberian dosis bokashi jerami padi tidak berpengaruh terhadap jumlah polong tanaman kedelai. Hubungan pemberian dosis bokashi jerami padi terhadap jumlah polong tanaman kedelai dapat dilihat pada Gambar 5.

\section{Jumlah Polong}

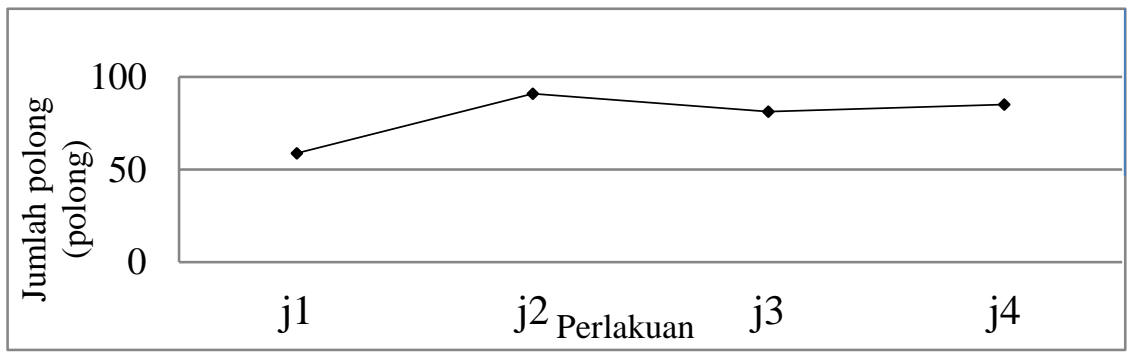

Gambar 5. Grafik pemberian dosis bokashi jerami padi terhadap jumlah polong pada tanaman kedelai.

Dari gambar terlihat bahwa pemberian dosis bokashi jerami padi menghasilkan jumlah polong tanaman kedelai yang terbanyak pada perlakuan $\mathrm{j}_{2}$ dengan nilai rata-rata 90,95 polong dan jumlah polong yang sedikit pada perlakuan $\mathrm{j}_{1}$ dengan nilai rata-rata 58,83 polong.

\section{Jumlah Biji}

Pengamatan jumlah biji pada tanaman kacang kedelai dilakukan pada saat tanaman sudah di panen. Berdasarkan hasil dari analisis ragam menunjukan bahwa pemberian dosis bokashi jerami padi tidak berpengaruh terhadap jumlah biji pada tanaman kacang kedelai. Hubungan pemberian dosis bokashi jerami padi terhadap jumlah biji tanaman kedelai dapat dilihat pada Gambar 6. Dari gambar dibawah terlihat bahwa pemberian dosis bokashi jerami padi menghasilkan jumlah biji tanaman kedelai yang terbanyak pada perlakuan $\mathrm{j}_{2}$ dengan nilai rata-rata 199,95 biji dan jumlah biji yang sedikit pada perlakuan $\mathrm{j}_{1}$ dengan nilai rata-rata 136,75 biji. 


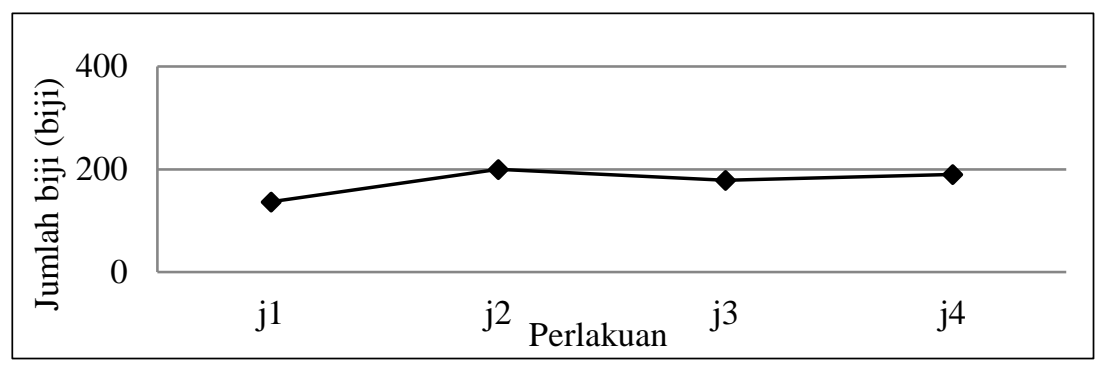

Gambar 6. Grafik pemberian dosis bokashi jerami padi terhadap jumlah biji pada tanaman kacang kedelai.

\section{Berat Kering 100 Biji}

Berdasarkan hasil dari analisis ragam menunjukan bahwa pemberian dosis bokashi jerami padi tidak berpengaruh terhadap berat kering 100 biji pada tanaman kedelai. Hubungan pemberian dosis bokashi jerami padi terhadap berat kering 100 biji tanaman kedelai dapat dilihat pada Gambar 7.

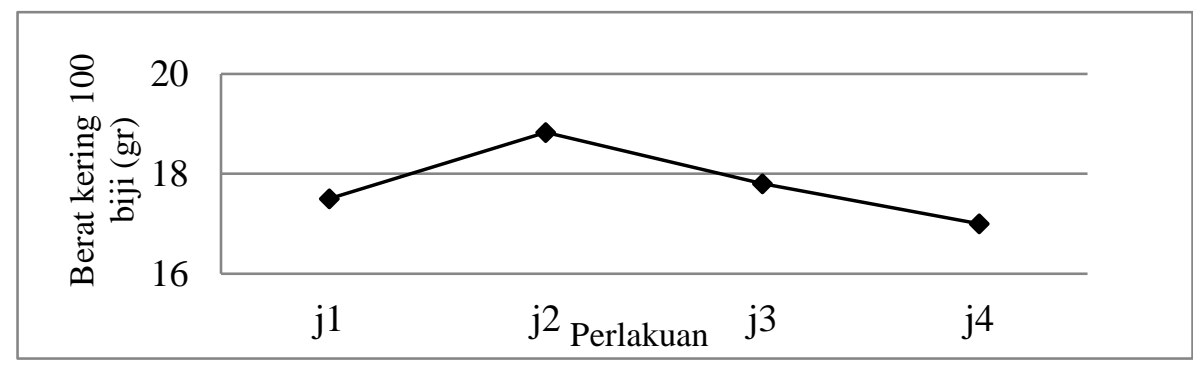

Gambar 7. Grafik pemberian dosis bokashi jerami padi terhadap berat kering 100 biji pada tanaman kedelai.

Dari gambar terlihat bahwa pemberian dosis bokashi jerami padi menghasilkan berat kering 100 biji tanaman kedelai yang terberat pada perlakuan $\mathrm{j}_{2}$ dengan nilai rata-rata $18,83 \mathrm{gr}$ dan berat kering 100 biji yang terendah pada perlakuan $\mathrm{j}_{3}$ dengan nilai rata-rata 17 gr.

\section{Pembahasan}

Berdasarkan analisis ragam menunjukan bahwa pemberian bokashi jerami padi yang difermentasikan dengan PGPR akar bambu tidak berpengaruh terhadap pertumbuhan dan hasil tanaman kedelai. Hal ini diduga bokashi jerami padi yang diberikan pada tanaman kedelai belum matang sempurna, dokumentasi bokashi jerami padi dapat dilihat pada Lampiran 20 Gambar 4. Menurut BPTP Kalimantan Tengah (2013), bokashi yang matang dicirikan dengan warna hitam, gembur, tidak panas, dan tidak berbau. Ketika kondisi seperti itu, bokashi telah dapat digunakan sebagai pupuk. Pada fase vegetatif tanaman kedelai sangat memerlukan unsur hara untuk menunjang pertumbuhan tanaman, hal ini memang terlihat pada hasil analisis tanah kandungan $\mathrm{N}, \mathrm{P}, \mathrm{K}$ dalam tanah tercukupi Ballitra (2018). Namun tidak berpengaruh karena proses dekomposisi yang belum matang sempurna maka mengakibatkan $\mathrm{C} / \mathrm{N}$ ratio pada bokashi jerami menjadi tinggi. Pusat Pelatihan Pertanian (2015), menyatakan bahwa bahan organik pada umumnya tidak dapat digunakan secara langsung oleh tanaman, karena perbandingan kandungan $\mathrm{C} / \mathrm{N}$ bahan tersebut tidak sesuai dengan $\mathrm{C} / \mathrm{N}$ tanah sehingga menyebabkan terjadinya immobilisasi, semakin tinggi $\mathrm{C} / \mathrm{N}$ ratio bahan organik semakin lama proses pengomposan. Proses perombakan atau peruraian bahan organik dengan bantuan mikroorganisme yang bersifat aerob (menggunakan udara) maupun anaerob (tanpa menggunakan udara) yang untuk hidupnya memerlukan $\mathrm{C}$ dan N. C 
(carbon) digunakan sebagai sumber energi sedangkan $\mathrm{N}$ (nitrogen) diperlukan untuk membentuk protein. Warino (2016), menjelaskan dekomposisi adalah perubahan senyawa yang komplek dalam bentuk senyawa organik menjadi senyawa yang lebih sederhana dalam bentuk anorganik sehingga dapat menyediakan unsur hara yang diperlukan oleh tanaman seperti unsur nitrogen, fosfor maupun Corganik. Menurut Sutanto (2005), bahwa terdapat 3 proses utama yang tumpang tindih pada proses dekomposisi, yaitu (1) proses biokimia, proses ini merupakan tahap awal proses dekomposisi yang terjadi setelah jaringan tanaman atau hewan mati. Tahapan ini terjadi sebelum proses hidrolisis dan oksidasi yang memecahkan senyawa polimer (pati menjadi gula, protein menjadi peptin dan asam amino), serta oksidasi senyawa bentuk fenol menjadi senyawa pewarna. (2) Peruraian secara mekanis menjadi bagian lebih kecil oleh kegiatan makrofauna dan mesofauna. Pada tahapan ini, bahan organik diurai menjadi bahan yang lebih halus tanpa mengalami perubahan komposisi. (3) Peruraian oleh mikroorganisme heterotrofik dan saprofitik. Pada tahapan ini dekomposisi bahan organik menjadi lebih sederhana. Hasil penguraian dimanfaatkan untuk pertumbuhan dan sumber energi. Tahap akhir peruraian oleh mikroorganisme adalah oksidasi (respirasi) yang menghasilkan $\mathrm{CO}_{2}$ dan $\mathrm{H}_{2} \mathrm{O}$ serta melepaskan energi. Pada saat yang bersamaan, $\mathrm{N}$ yang masih berbentuk $\mathrm{NH}_{4}$ akan mengalami nitrifikasi menjadi $\mathrm{NO}_{3}{ }^{-}$, $\mathrm{P}$ berbentuk senyawa fosfat, $\mathrm{S}$ sebagai sulfat, serta $\mathrm{K}, \mathrm{Ca}$, dan $\mathrm{Mg}$ berbentuk bebas atau ion yang terikat dengan senyawa lain.

Bahan organik yang berasal dari sisa tanaman mengandung bermacammacam unsur hara yang dapat dimanfaatkan kembali oleh tanaman jika telah mengalami dekomposisi dan mineralisasi. Sisa tanaman ini memiliki kandungan unsur hara yang berbeda kualitasnya tergantung pada tingkat kemudahan dekomposisi serta mineralisasinya. Margo (2008), menyatakan bahwa gula, protein sederhana adalah bahan yang mudah terdekomposisi, sedangkan lignin yang akan lambat terdekomposisi. Secara urutan, kemudahan bahan yang untuk terdekomposisi adalah sebagai berikut : (1) gula, zat pati, dan protein sederhana merupakan bahan yang mudah terdekomposisi, (2) Protein kasar, hemiselulosa, selulosa, lemak, lignin dll merupakan bahan organik yang sangat lambat terdekomposisi.

Margo (2008), kemudahan dekomposisi bahan organik berkaitan erat dengan nisbah kadar hara. Secara umum, makin rendah nisbah (rasio atau perbandingan) antara kadar $\mathrm{C}$ dan $\mathrm{N}$ di dalam bahan organik, akan semakin mudah dan cepat mengalami dekomposisi. Oleh karena itu, untuk mempercapat dekomposisi bahan organik yang memiliki nisbah $\mathrm{C}$ dan $\mathrm{N}$ tinggi disarankan untuk menambakan pupuk nitrogen dan kapur dolomit untuk memperbaiki perbandingan kedua hara tersebut serta menciptakan kondisi lingkungan yang lebih baik bagi dekomposer. Selama proses dekomposisi bahan organik, terjadi immobilisasi dan mobilisasi (mineralisasi) unsur hara. Immobilisasi yaitu perubahan unsur hara dari bentuk anorganik menjadi bentuk organik yang terinkorporasi (tergabung) dalam biomasa organisme dekomposer. Sedangkan mineralisasi terjadi sebaliknya. Mineralisasi dan immobilisasi kedua kegiatan ini tergantung pada proporsi (keseimbangan) kadar hara dalam bahan organik. Immobilisasi nitrogen secara nettro terjadi bila nisbah antara $\mathrm{C}$ dan $\mathrm{N}$ bahan orgnik lebih dari 30, sedangkan mineralisasi nettro terjadi keseimbangan antara immobilisasi dan mineralisasi. Immobilisasi dan mineralisasi tidak hanya terjadi pada unsur nitrogen, tapi juga terjadi pada unsur lain. Pada saat terjadi immobilisasi tanaman akan sulit menyerap hara karena terjadi persaingan dengan dekomposer. Oleh karena itu, perberian bahan organik perlu memperhitungkan kandungan hara dalam bahan organik tersebut. Bahan organik yang memiliki nisbah $\mathrm{C}$ dan $\mathrm{N}$ rendah, cepat menyediakan hara bagi tanaman, sedangkan bila bahan 
organik memiliki nisbah $\mathrm{C}$ dan $\mathrm{N}$ yang tinggi akan terjadi immobilisasi hara. Selain tidak matangnya bahan organik yang diberikan, kondisi $\mathrm{pH}$ tanah yang masam dan kurangnya unsur hara mikro juga dapat menghambat pertumbuhan dan hasil tanaman. Berdasarkan hasil analisis tanah Laboratorium Ballitra (2018), bahwa lahan penelitian di Desa Pembakulan, Kecamatan Batang Alai Timur Kabupaten Hulu Sungai mengandung $\mathrm{pH}$ tanah yang rendah dan bersifat masam yaitu 5,15. Selanjutnya Novizan (2002) dalam Efendi (2010), mengemukakan bahwa ada tiga sisi negatif dari tanah yang bersifat asam, yakni unsur hara makro tidak tersedia dalam jumlah yang cukup, namun sebaliknya, unsur hara mikro yang bersifat racun bagi tanaman justru tersedia dalam jumlah berlebihan. Selain itu, tanah yang terlalu masam dapat menghambatperkembangan mikroorganisme di dalam tanah. Kondisi tersebut akan berpengaruh negatif bagi pertumbuhan dan perkembangan tanaman. Sudarmi (2013), menyatakan Unsur hara mikro ( $\mathrm{Fe}, \mathrm{Zn}, \mathrm{Cu}$, $\mathrm{Mo}, \mathrm{Cl}$ dan B) termasuk unsur hara esensial sehingga harus selalu tersedia bagi tanaman, meskipun dibutuhkan oleh tanaman dalam jumlah sedikit. Karena unsur hara mikro mempunyai fungsi yang spesifik dalam pertumbuhan dan perkembangan tanaman serta fungsinya tidak dapat digantikan secara sempurna oleh unsur hara lain. Oleh karena itu untuk menjaga pertumbuhan tanaman secara normal supaya tidak mengganggu produksi dan mutu, maka dalam budidaya tanaman selain ditambahkan unsur hara makro ( pupuk N, P, K) juga perlu ditambahkan unsur hara mikro, terutama pada keadaankeadaan dimana unsur hara mikro dapat membatasi pertumbuhan tanaman. Pada fase generatif terjadi perkembangan cenderung naik turun hal ini dikerenakan sebagian bahan organik sudah dapat dimanfaatkan oleh tanaman, tetapi tidak berpengaruh terhadap hasil tanaman kedelai, perombakan bahan organik akan lebih cepat jika dalam jumlah yang sedikit, pada perlakuan $\mathrm{j}_{1}$ proses dekomposisinya terjadi lebih cepat, namun karena jumlahnya terlalu sedikit pada perlakuan $\mathrm{j}_{1}$ kebutuhan unsur hara tidak mencukupi bagi tanaman, pada perlakuan $\mathrm{j}_{2}$ proses dekomposisi terjadi lebih cepat dan jumlah bahan organiknya juga cukup banyak pada perlakuan $\mathrm{j}_{2}$ cenderung terjadi peningkatan pertumbuhan maupun pada hasil tanaman kedelai, hal ini diduga pada perlakuan $\mathrm{j}_{2}$ lebih menyediakan unsur hara dibandingkan perlakuan yang lainnya. Pada perlakuan $\mathrm{j}_{3}$ dan $\mathrm{j}_{4}$ karena jumlah bahan organik lebih banyak sehingga menyebabkan proses dekomposisi menjadi lambat sehingga tidak dapat menyediakan unsur hara yang cukup bagi tanaman. Firmansyah (2010) menyatakan lapisan bahan organik yang lebih tipis dari permukaan tanah berhubungan erat dengan laju dekomposisi, semakin tebal lapisan bahan organik di permukaan tanah maka terdekomposisinya lebih lama. Menurut Novizan (2002) dalam Efendi (2010), menyatakan bahwa unsur hara yang berasal dari pupuk organik sebagian kecil dapat langsung dimanfaatkan oleh tanaman, namun sebagian lagi terurai dalam jangka waktu yang lama. Unsur hara yang terurai tersebut kemudian dapat dimanfaatkan oleh tanaman sebagai bahan makanan untuk menujang perkembangan tanaman. (Musnamar, 2005) dalam Efendi (2010), menyatakan atas bantuan jasad renik di dalam tanah bahan organik akan diubah menjadi bentuk sederhana yang dapat diserap tanaman berupa unsur hara.

\section{KESIMPULAN}

Pemberian berbagai dosis bokashi jerami padi tidak memberikan pengaruh terhadap pertumbuhan dan hasil tanaman kadelai. Tidak didapatkan dosis bokashi jerami padi terbaik pada semua variabel pengamatan pertumbuhan dan hasil tanaman kedelai.

\section{DAFTAR PUSTAKA}

Ballitra. (2018). Hasil analisis tanah Desa Pembakulan. Banjarbaru: Laboratorium Tanah dan Air Ballitra. 
Sariyu Erwan, Nurul Istiqomah \& Mahdiannoor, Pemberian berbagai dosis bokashi...

BPS Hulu Sungai Tengah. (2017). Kabupaten Hulu Sungai Tengah dalam Angka. Barabai: BPS Kabupaten Hulu Sungai Tengah.

BPTP Kalimantan Tengah. (2013). Membuat Kompos Dengan Aktivator EM4. Palangka Raya: BPTP Kalimantan Tengah,

Pusat Pelatihan Pertanian. (2015). Pemupukan Jagung. Bogor: BPPSDMP.

Efendi. (2010). Peningkatan pertumbuhan dan produksi kedelai melalui kombinasi pupuk organik lamtorogung dengan pupuk kandang. J. Floratek 5: 65 -73.

Firmansyah, M, A. (2010). Teknik Membuat Kompos. Palangka Raya: BPTP Kalimantan Tengah.

Kusumawardhani, R., \& Tyas, T. A. (2015). Pemanfaatan Jerami Padi Menjadi Pupuk Organik Dan Wahana. Seminar Nasional Universitas PGRI Yogyakarta (pp. 198-202). Yogyakarta: Universitas PGRI Yogyakarta.

Langai, B.F. (2003). Buku Ajar Rancangan Percobaan. Banjarbaru: Fakultas Pertanian Universitas Lambung Mangkurat.

Yuwono, M. (2008). Dekomposisi Dan Mineralisasi Empat Macam Bahan Organik. Jurnal Agronomi, 12(1), 49-58.
Mulyana, D. Sakhidin, \& Iqbal, A. (2011). Pengaruh Dosis Bokashi terhadap Pertumbuhan dan Hasil Tiga Varietas Padi. Agrin : Jurnal Penelitian Pertanian, 15(1), 18-26. DOI: http://dx.doi.org/10.20884/1. agrin.2011.15.1.115

Pambudi, S. (2013). Budidaya dan Khasiat Kedelei Edamame Camilan Sehat dan Multi Manfaat. Yogyakarta: Pustaka Baru Press.

Salim, E. (2012). Kiat Cerdas Wirausaha Aneka Olahan Kedelai. Yogyakarta: Andi.

Susetyo, N.A. (2013). Pemanfaatan Urin Sapi sebagai POC (Pupuk Organik Cair) dengan Penambahan Akar Bambu Melalui Proses Fermentasi Dengan Waktu yang Berbeda. Naskah Publikasi Penelitian. Retrieved from http://eprints.ums. ac.id/26749/24.

Susmiati. (2013). Pupuk Bokashi Dan Faktor-Faktor yang Berpengaruh terhadap Pengomposan Bokashi. Jurnal Pertanian, 1(1).

Sutanto, R. (2005). Dasar-Dasar Ilmu Tanah Konsep dan Kenyataan. Yogyakarta: Penerbit Kanisius.

Warino, J. (2015, Agustus 25). Ilmu Tanah. Retrieved from Jokowarino.ID: http://jokowarino. id/. 